\title{
THE OPERATION OF THE ESGAPE GLAUSES IN THE ROME CONVENTION, ROME I REGULATION AND ROME II REGULATION
}

\author{
CHUKWUMA SAMUEL ADESINA OKOLI* AND \\ GABRIEL OMOSHEMIME ARISHE**
}

\section{A. Introduction}

An escape clause is a provision inserted in a legal instrument to supplement or cure the defect in the main rule, especially where the main rule has little or no connection with the issue to be resolved before the court. ${ }^{1}$ Escape clauses honour the claim that no legal instrument is perfect and strive to improve the instrument by giving the court the discretion to locate the law of a country that is more or most closely connected with the subject-matter. ${ }^{2}$ This feature in an escape clause makes it deserving of special attention.

The escape clauses in the Rome Convention, ${ }^{3}$ Rome I Regulation (Rome I ${ }^{4}$ and the Rome II Regulation (Rome II) ${ }^{5}$ have at least four similar features. First,

* LLB (Hons), BL (Hons), LLM Distinction (International Commercial Law) University of Aberdeen. This paper is based on the dissertation I submitted to the University of Aberdeen during my LLM programme. I dedicate this article to my mother (Mrs FN Okoli) who primarily funded my LLM programme. I wish to express my profound gratitude to Prof Paul Beaumont for his initial advice as the supervisor of my dissertation; and subsequent comments, suggestions, criticisms and careful editing of the earlier draft of the article; and Dr Christa Roodt, for her comments, which I found useful in this area of private international law. The authors wish to thank the anonymous referees for their very insightful comments and criticisms. The authors take sole responsibility for the views expressed in this publication and would welcome criticisms sent to chuksamde@yahoo.com.

** LL.B (Hons); LL.M; PhD (Law) Candidate, Faculty of Law, University of Benin, Benin City, Nigeria.

$1 \quad$ SC Symeonides, "Rome II and Tort Conflicts: A Missed Opportunity" (2008) 56 American Fournal of Comparative Law 173, 197.

Ibid.

On the law applicable to contractual obligations [1980] OJ L266.

Regulation (EC) No. 593/2008 of the European Parliament and of the Council of 17 June 2008 on the law applicable to contractual obligations [2008] OJ L177/6. Art 29 Rome I provides that it shall apply from 17 December 2009. It replaces the Rome Convention.

5 Regulation (EG) No 864/2007 of the European Parliament and of the Council of 11 July 2007 on the law applicable to non-contractual obligations [2007] OJ L19940. It takes effect in courts of Member States only to events giving rise to damage occurring after 11 January 2009, as decided by the Court of Justice of the European Union (CJEU) in Case C-412/10 Homawoo v GMF Assurances SA [2012] ILPR 2 [37]. The English courts in Innovia Films Limited v Frito-Lay North America Inc [2012] EWHC 790 [100]; VTB Capital Plc v Nutritek International Corp 
the three instruments generally adopt geographical or jurisdictional selection rules in deploying the escape clause as opposed to 'better law' or substantive justice principles inherent in some US systems. ${ }^{6}$ Secondly, they usually involve the weighing of contacts to the dispute involved in order to identify the law of the country that appears more or most closely connected to the dispute. Thirdly, they place the burden of proof on the party who relies on the escape clause to displace the main rule. ${ }^{7}$ Fourthly, they face the tension of meeting the requirements of legal certainty and the need to do justice in individual cases.

This paper takes a critical look at the operation of the escape clause in the Rome Convention, Rome I and Rome II and different approaches are identified and discussed with regard to deploying the escape clause in those instruments. In Section B, the writers defend the intermediary approach as appropriate to the deployment of the escape clause under the Rome Convention. Special attention is also given to the confusion created among English courts on the connection between an implied choice of law and law in the absence of choice as it concerns deploying the escape clause under the Rome Convention. This paper proposes the deletion of the doctrine of implied choice of law in order to create certainty in deploying the escape clause.

In Section $\mathrm{C}$, it is advocated that the strong presumption approach is the appropriate approach in deploying the escape clause in Rome I. The writers utilise recent judicial decisions in England as a basis for identifying the difference between the threshold of displacement under Rome I and the Rome Convention.

In Section D, the writers advocate a functional intermediary approach as appropriate in deploying the escape clause in Rome II. The writers utilise

[2012] EWCA Giv 808 [145]; and Alliance Bank 7SC v Aquanta Corp [2012] EWCA [37]-[38] recently followed the CJEU's decision in Homawoo. However, Burton J in Alliance Bank [37]-[38] queries the CJEU's decision as not clearing the doubt as to whether the date that applies is the one when the damage manifests itself or the event that gives rise to the resulting damage. He [reluctantly] prefers the former interpretation on the ground that Art 4(1) and (2) Rome II are concerned with the "law of the country where the damage occurs", despite the fact that the escape clause in Art 4(3) apparently does not restrict itself to the general rule in Art 4(1) and (2). See also earlier English cases on the controversy as to when the Rome II comes into operation: Bonsall v Cattolica Assicurazioni [2010] ILPR 45 [8]; Bacon v Nacional Suizaciga [2010] EHWC 2017 (QB) [61]; Homawoo v GMF Assurance [2010] EHWC 1941 [43]-[52]; Lucas Film Limited v Ainsworth [2011] UKSG 39 [91]; Hillside (New Media) Limited v Biarte Baasland [2010] EHWC 1941 (QB) [23]-[25].

6 Credit Lyonnais v New Hampshire Insurance Company [1997] CLC 909, 916; Symeonides, supra n 1, 181; JJ Fawcett and JM Carruthers, Cheshire North and Fawcett, Private International Law (Oxford University Press, 14th edn, 2008), 710; R Fentiman, "The Significance of Close Connection", in J Ahern and W Binchy (eds), The Rome II Regulation on the Law Applicable to Non-ContractualObligations: A New International Litigation Regime (Martinus Nijhoff, 2009), 85, 94.

Samcrete Egypt Engineers v Land Rover Exports Limited [2001] ECWA 2019 [37]; British Arab Commercial Bank Plc v Bank of Communications and Commercial Bank of Syria [2011] EWHC 281 (Comm) [31]; Lawlor v Mining and Construction Mobile Crushers Screens Ltd [2012] EWHC 1188 [53]; Dicey, Morris and Collins, Conflict of Lawe, 1st Suppl (Sweet and Maxwell, 14th edn, 2007), S35-197. 
recent English and Irish court decisions, and existing academic authorities to discuss the appropriate way to deploy the escape clause in Rome II. Other factors which are considered include the relevance of a pre-existing relationship between the parties and the accessory connection between a choice of law under a contract while deploying the escape clause under Rome II.

Section E contains the conclusion of this paper.

\section{B. The Escape Glause in the Rome Convention}

Article 3 of the Rome Convention stipulates that parties to a contract can make an express choice of law or one that can be implied by a court with reasonable certainty from the terms of the contract or the circumstances of the case. However, parties to a contract may fail to make a valid choice of law. Three of the main reasons why this happens are: ${ }^{8}$ first, the parties may overlook the possibility of making a choice of law to govern their contract; secondly, the parties may fail to agree on a choice of law that governs their transaction; and thirdly, there may be vitiating elements such as fraud, illegality and duress in reaching the choice of the applicable law that renders the choice of law made by the parties void.

It is in recognition of the above problems that Article 4 of the Rome Convention provides for the determination of the law that governs a contract in the absence of a choice made by the parties. Article 4(1) provides that the choice of law is to be determined by the law of the country that is most closely connected with the contract. It also provides that a severable part of a contract which has a closer connection with another country may by way of exception be governed by the law of that country. This proviso (also known as dépeçage) is to be utilised by a court on exceptional grounds, especially where the contract is independent and can be severed from the rest of the other contracts. ${ }^{9}$

Article 4(2) provides that subject to Article 4(5) "it shall be presumed that the law of the country that is most closely connected shall be the law of the [habitual residence] of the party who is to carry out the performance which is characteristic of the contract". Article 4(5) provides that the presumption in paragraph 2 shall not apply if the "characteristic performance cannot be determined" and it shall also be disregarded "if it appears from the circumstances as a whole that the contract is more closely connected with another country".

8 U Magnus, "Article 4 Rome I Regulation: The Applicable Law in the Absence of Choice", in S Ferrari and S Leible (eds), Rome I Regulation: The Law Applicable to Contractual Obligations in Europe (Sellier, 2009), 27.

9 C-133/08 Intercontainer Interfrigo SC (ICF) v Balkenende Oosthuizen [2009] ECR I-9687 [42], [43], [45], [46], [48], [49]; Giuliano-Lagarde Report [1980] OJ C282/1, 23 
The determination of what constitutes the "performance which is characteristic of the contract" is not explained in the text of the Rome Convention. Giuliano and Lagarde ${ }^{10}$ in their commentary explained that it "is performance for which the payment is due ... which usually constitutes the centre of gravity and the socio-economic function of the contractual transaction". Identification of the characteristic performer in unilateral contracts like sales of goods, production of services and guarantee contracts is not as difficult ${ }^{11}$ as identifying the characteristic performance in complex bilateral transactions involving mutual performance such as distributorships, franchise, letters of credit, joint ventures and intellectual property, which appears controversial and near impossible. ${ }^{12}$ A second disadvantage of the doctrine is that the habitual residence of the characteristic performer may have little or no connection with the contract in question. ${ }^{13}$ Thirdly, the undue preference for the law of the country of the habitual residence of the characteristic performer as a presumptive connecting factor unfairly downplays the law of the other party as a connecting factor. ${ }^{14}$

The advantage of the doctrine is that the characteristic performer may "easily have knowledge in particular without a language barrier, and that on which he may legitimately rely"15 on the law of the place of his habitual residence. Secondly, by reason of its professional activity, the "supplier of the characteristic performance will enter into a large number of contracts. It therefore appears reasonable for practical reasons that all of the contracts which it concludes should be subject to the same law."16

Having regard to the above pros and cons on the doctrine of characteristic performance, courts of Member States and academic commentators were in disagreement on the proper relationship between Articles 4(2) and 4(5) in determining the law of the country that is most closely connected to the contract in the absence of a choice of law.

Four major approaches feature in judicial opinions and academic writings on the appropriate way to utilise the escape clause in the Rome Convention. These approaches are (i) the weak presumption approach, (ii) the strong pre-

10 Giuliano-Lagarde Report, ibid, 23.

11 Ibid. Samcrete, supra n 7, [38]; British Arab Commercial Bank ple v BOC [2011] EWHC 28 [31]; of Golden Ocean Group Limited v Salgaocar Mining Industries PVT Ltd and Salgaocar [2012] EWCA Civ 265 [52], where Tomlinson LJ in his leading judgment (with whom the rest of the Court agreed) in the English Court of Appeal decided that he could not identify the characteristic performer in a unilateral contract of warranty of authority.

12 Supra n 9, 23. Print Concept GmbH v GEW (EC) Ltd [2001] CLC 352 [34]; Marconi Communications International v PT Pan Indonesia Bank Ltd [2005] ECWA 422 [61]; Apple Corps Limited v Apple Computers Incorporated [2004] 2 CLC 720 [46]-[56].

13 Definitely Maybe v Marek Lieberberg [2001] I WLR 1745 [12]; Cheshire, North and Fawcett, supra n $6,714-15$.

14 Ibid.

15 Intercontainer, supra n 9, Opinion of AG Bot [45].

16 Ibid, [46]; see generally R Plender and M Wilderspin, European Private International Law of Obligations (Sweet \& Maxwell, 3rd edn, 2009), 168-69. 
sumption, (iii) the intermediary approach, and (iv) the doctrine of commercial expectations. These approaches expose the tension between flexibility and justice in individual cases on the one hand; and legal certainty, predictability and uniformity in addressing choice-of-law problems in commercial transactions under the Rome Convention on the other hand. These approaches are reviewed below.

\section{The Weak Presumption Approach ${ }^{17}$}

The weak presumption approach has also been labelled as the English, French and Danish approach. ${ }^{18}$ In the case of Credit Lyonnais, Hobhouse LJ labelled the presumption in Article 4(2) as "very weak". ${ }^{19}$

English common law was not used to utilising the technique of using the presumption of characteristic performance to determine the law applicable to a contract in the absence of choice. ${ }^{20}$ But the principle of close connection in determining the law that applies to a contract was part of the common law and probably influenced its approach in the determination of the applicable law in the absence of choice. ${ }^{21}$ Thus, English courts were quick to disregard the presumption of characteristic performance in favour of other connecting factors in determining the law that applies to a contract based on deploying the escape clause in Article 4(5). The relationship between Article 4(2) and (5) was described as "a tie-breaker" that could tilt in favour of the law of the country that is most closely connected to the contract based on the centre of gravity of the commercial transaction. ${ }^{22}$

However, it must be noted that some English courts wanted to be seen as paying respect to the presumption in Article 4(2)..$^{23}$ In some other cases, English courts discussed the various approaches to the interpretation of the escape clause under the Rome Convention and claimed to steer a middle course. ${ }^{24}$ The underlying and most consistent factor of the weak presumption approach (especially in English cases) can be found in the early proposition of Dicey and

17 See generally J Hill, "Choice of Law in Contract under the Rome Convention: The Approach of the UK Courts" (2004) 53 International and Comparative Law Quarterly 325; WE O'Brian, "Choice of Law under the Rome Convention: The Dancer or the Dance" [2004] Lloyd's Maritime and Commercial Law Quarterly 375.

${ }_{18}$ Intercontainer, supra n 9, opinion of AG Bot, [73]; Plender and Wilderspin, supra n 16, 174-75.

19 Supra $n$ 6, 914.

20 Dicey, Morris and Collins, supra n 7, vol 2, 1581; Cheshire, North and Fawcett, supra n 6, 708-

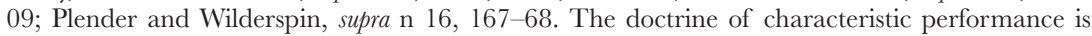
historically a Swiss doctrine.

21 Ibid. Bonython v Australia [1951] AC 201, 221-23; Definitely Maybe, supra n 13, [7].

22 Caledonia Subsea Ltd v Microperi Srl 2002 SLT 1022 [28] (Lord President Cullen).

23 Eg Samcrete, supra n 7, [41]; Ennstone Building Products Ltd. v Stranger Ltd [2002] 1 WLR 3059, 3067, 3070; Opthalmic Innovations Limited (U.K.) v Opthalmic Innovations International Incorporated (USA) [2004] EHWC 2948 [48], [49], [53].

24 Definitely Maybe, supra n 13, [14]-[15]. 
Morris; that the presumption in Article 4(2) "may most easily be rebutted in those cases where the place of performance differs from the place of business of the party whose performance is characteristic of the contract". ${ }^{25}$

Thus, in most English cases, the courts were quick to disregard the presumption in Article 4(2) where the place of performance differed from the place of business of the party who is to effect the characteristic performance. ${ }^{26}$ In the same vein, it is also observed that an English court refused to disregard the presumption in Article 4(2), where the place of business of the party who was to effect the characteristic performance was also the place of performance. ${ }^{27}$

English courts did, however, give consideration to other connecting factors such as the country's currency of payment, ${ }^{28}$ the place of negotiation or conclusion of the contract; ${ }^{29}$ the place of residence of the parties and object of the contract; ${ }^{30}$ and the place of payment ${ }^{31}$ in disregarding the presumption; but it unduly elevated the place of performance as a connecting factor in most of its decisions.

The advantage of the weak presumption approach is that it shows that in determining the closest connection with the country and contract, the habitual residence of the characteristic performer may in many cases have no connection with the contract in question. ${ }^{32}$ Secondly, it made the escape clause in the Rome Convention a strong tool in addressing choice-of-law problems in commercial transactions by flexibly locating the law that is most closely connected to the contract in question.

The disadvantage of the weak presumption approach is that it functionally made the presumption in Article $4(2)$ of no material significance by disregarding it quite often through the deployment of the escape clause thereby undermining legal certainty. ${ }^{33}$ Secondly, the undue elevation of the place of performance as a special connecting factor in disregarding the presumption in

25 Dicey, Morris and Collins, The Conflict of Laws (Sweet \& Maxwell, 13th edn, 2000), vol 2, 32-124.

26 Credit Lyonnais, supra n 6, 915-16; Bank of Baroda v Vysa Bank Limited [1994] CLC 41, 47; Definitely Maybe, supra n 13, [15]; Samcrete, supra n 7, [47]; Kenburn Waste Management Ltd v Bergmann [2002] EWCA 99 [20]-[23]; Marconi Communication, supra n 12, [66]; Commercial Marine Piling Limited v Pierse Contracting Limited [2009] EHWC 2241 [33]-[37]. Such was the undue elevation of the "place of performance" as a connecting factor that in Kenburn, ibid, [20]-[23], Walker LJ corrected the expression made by the lower court judge who referred to Art 4(2) of the Rome Convention as the "place of characteristic performance" instead of "performance which is characteristic of the contract" or the "characteristic performance" as abbreviated in para 5. Iran Continental Shelf Oil Co Ltd v IRI International Corp [2004] CLC 696 [20], [87]-[91], [94].

Definitely Maybe, supra n 13, [8].

Ibid. Opthalmic Innovations, supra n 23, [32], [49].

Opthalmic Innovations, supra n 23, [32], [49].

Samcrete, supra n 7, [47]; Commercial Marine, supra n 26, [33].

Definitely Maybe, supra n 13, [12].

3 PA De Miguel Asensio, "Applicable Law in the Absence of Choice to Contracts Relating to Intellectual or Industrial Property Rights" (2008) 10 Yearbook of Private International Law 199, 203. 
Article 4(2) has no textual legitimacy in Article 4 of the Rome Convention. ${ }^{34}$ The place of performance ought to be considered alongside other material connecting factors in determining whether it is justifiable to disregard the presumption of characteristic performance in Article 4(2). Thirdly, the escape clause was abused in such a way that the law of the forum was often interpreted by courts of Member States to be the most closely connected law in the absence of choice. $^{35}$

\section{The Strong Presumption Approach}

The strong presumption approach has also been labelled as the Dutch and Scottish approach. ${ }^{36}$ The approach was primarily given judicial endorsement by the Supreme Court of the Netherlands in the case of Société Nouvelle des Papeteries de l'AA SA v BV Machinefabriek $B O A .{ }^{37}$ In that case it was held that the escape clause in Article 4(5) should hardly be utilised as "the main rule should be disregarded only if, in the special circumstances of the case, the place of business of the party who is to effect the characteristic performance has no real significance as a connecting factor". 38

This trend of judicial thinking was followed by a majority of the members of the Court of Session in the Scottish case of Caledonia ${ }^{39}$ who reasoned that "the presumption must be strong and only in exceptional circumstances or very special circumstances can it be disregarded under Article 4(5)". ${ }^{40}$ The majority defended the strong presumption approach as advocated by the Dutch Supreme Court on three main grounds. First, it supported the underlying objective of Article 4 in promoting certainty and uniformity in determining the applicable law in the absence of choice. ${ }^{41}$ In other words, it was also honouring the claim in Article 18 of the Rome Convention that the Rome Convention should be interpreted with an objective international flavour and not with a domestic bias. Secondly, "looking for the law of the country in which the performance takes place is not the primary aim in any determination of what is to be the applicable law"42 as was done by most English Courts. Thirdly, it is only by giving considerable weight to the presumption of characteristic performance

\footnotetext{
Caledonia, supra n 22, [41].

35 THD Struckyen, "Some Dutch Reflections on the Rome Convention, Art 4(5)" [1996] Lloyd's Maritime and Commercial Quarterly 18; Samcrete, supra n 7, [42]; E Lein, "The New Rome I/Rome II/Brussels I Synergy" (2008) 10 Yearbook of Private International Law 177, 185.

36 Intercontainer, supra n 9, Opinion of AG Bot [71]-[72].

37 [1992] Nederlandse jurisprudentie 750; reaffirmed in Baros AG (Switzerland) v Embrica Martim Hotelschiffe GmBH [Hoge Road, 17 October 2008, No C07/037HR; LJN: BE7201].

38 Interpreted originally in Struycken, supra n 35, 20.

39 Caledonia, supra n 22, [3], [6] (Lord Cameron); [2]-[4] (Lord Marnoch); rejected by the English Courts in Samcrete, supra n 7, [42] and Marconi Communications, supra n 12, [48].

40 Caledonia, supra n 22.

41 Ibid.

42 Ibid.
} 
in Article 4(2) "that the real and practical effect can be given to the objective of Article 4 . . namely that of clarifying and simplifying the law". ${ }^{43}$ In other words, the constant use of the escape clause complicated the determination of what the applicable law in a contract should be in the absence of choice.

The main advantage of the strong presumption approach is that parties can easily determine what law applies to their transaction if they fail to make a choice. It is highly attractive for the parties to make an express choice of law under Article 3 of the Rome Convention so as to avoid the inflexible rules of the strong presumption approach. ${ }^{44}$

The major criticism of the strong presumption approach is that it construed the relevant phrase in Article 4(5) as if it were to be read as "manifestly more closely connected" and failed to give due consideration to the relevant phrase that "if it appears from the circumstances as a whole that the contract is more closely connected with another country", the presumption in paragraph 2 "shall be disregarded". Secondly, the primary aim of Article 4 of the Rome Convention is to determine the law of the country which is most closely connected to the contract in the absence of choice. ${ }^{45}$ Thus, the excessive concern with the presumption in Article 4(2), where there are other justifiable connecting factors that require disregarding the main presumption, makes the strong presumption approach open to objection. ${ }^{46}$ Thirdly, the strong presumption approach made the escape clause in Article 4(5) of the Rome Convention of little utility in locating the law of the country that was most closely connected to the contract where the parties for good reasons failed to agree on a choice of law.

\section{Fentiman's Theory of Commercial Expectations}

Fentiman is credited with expressly propounding the above theory in academic writings. ${ }^{47}$ The theory was further reformulated by Atrill ${ }^{48}$ and adopted by Fentiman in its refined form. ${ }^{49}$ The theory asserts that the true purpose for the justification of the deployment of the escape clause in disregarding the presumption of characteristic performance is not expressly stated in the Rome Convention. ${ }^{50}$ In other words, the Rome Convention neither makes an exhaustive list of connecting factors that justify using the escape clause nor provides

43 Ibid.

44 JV Hein, "The Contribution of the Rome II Regulation to the Communitarisation of Private International Law" (2009) 73(3) Rabelsz 461, 484.

45 Intercontainer, supra n 9, [26], [54].

46 Caledonia, supra n 22, [38] (Lord President Cullen).

47 "Commercial Expectations and the Rome Convention" (Case Comment) (2002) 61(1) Cambridge Law fournal 50; Fentiman, supra n 6, 94-98; R Fentiman, International Commercial Litigation (Oxford University Press, 2010), 212-26.

48 S Atrill, "Choice of Law in Contract: the Missing Pieces of the Article 4 Jigsaw" (2004) 53(3) International and Comparative Law Quarterly 549.

49 Fentiman, supra n 6, 94-98; Fentiman, supra n 47, 212-26.

50 Fentiman, supra n 6, 98; Fentiman, supra n 47, 214-16. 
the measure of significance or weight to be attached to these factors in disregarding the presumption of characteristic performance. ${ }^{51}$ The rationale for this is that the European drafters of the Rome Convention did not intend to fetter the discretion of the courts of Member States in ascertaining what material connecting factors justify the utilisation of the escape clause in disregarding the presumption of characteristic performance. ${ }^{52}$ Fentiman states the main purpose of Article 4 of the Rome Convention is to identify the commercial gravity of a contract. Thus, a purposive approach which looks into the socioeconomic function of the contract is required in determining whether the escape clause should be utilised in disregarding the presumption in Article 4(2); and not a "mere accumulation of connecting factors" or "an arithmetical preponderance of elements" or "simply a matter of judicial intuition". ${ }^{33}$ The theory posits that close connection is a significant connection and "requires a court to give such weight to connecting factors as reflects their practical importance". ${ }^{44}$ It is also stated that the strong and weak presumption approaches are not useful in this task because they offer a deceptive choice between the requirements of legal certainty and flexibility in commercial transactions. ${ }^{55}$

Fentiman submits that the purpose of the escape clause in Article 4(5) of the Rome Convention is

“intended to capture a contract's commercial context and presumably thereby to ensure its commercial effectiveness, and indirectly the parties' expectation that their contract shall be commercially viable. The animating principle is that the significance of the relevant connecting factors should be assessed in commercial terms." ${ }^{256}$

Thus, it is advocated that in justifying the deployment of the escape clause in disregarding the presumption of characteristic performance, material connecting factors such as the place of performance or payment, object of the contract, and the closeness of one contract to another are of commercial significance to the parties involved in a contract and should be given due attention by the court. However, connecting factors such as the place where the contract was negotiated or concluded; the language in which the contract was expressed; reference to a foreign law; and the country's currency of payment are not of any commercial significance to the parties involved in a contract.

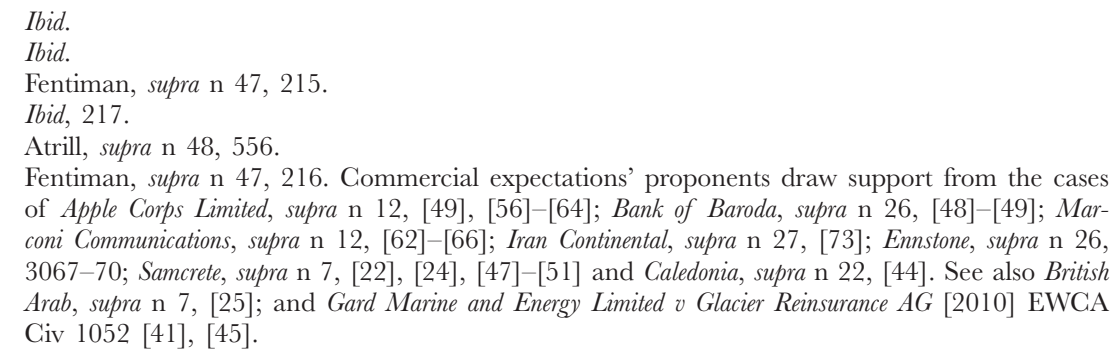
of Apple Corps Limited, supra n 12, [49], [56]-[64]; Bank of Baroda, supra n 26, [48]-[49]; Marconi Communications, supra n 12, [62]-[66]; Iran Continental, supra n 27, [73]; Ennstone, supra n 26, 3067-70; Samcrete, supra n 7, [22], [24], [47]-[51] and Caledonia, supra n 22, [44]. See also British Arab, supra n 7, [25]; and Gard Marine and Energy Limited v Glacier Reinsurance AG [2010] EWCA Civ 1052 [41], [45]. 
The advantage of the commercial expectations theory is that it offers an economically pragmatic solution in justifying which factors are significant or material in disregarding the presumption of characteristic performance in a contract where the parties fail to make a choice.

However, it is open to three main objections. First, the doctrine of commercial expectations has no textual legitimacy in the Rome Convention. Secondly, the theory is likely to produce almost as much uncertainty as the weak presumption approach. The determination of whether a connecting factor meets the commercial expectations of a contract; or the determination of the measurement or assessment of a contract's commercial significance will in a variety of cases amount to embarking on a voyage of discovery beyond the scope envisaged by the Rome Convention. Thirdly, Article 4(5) is concerned with the circumstances as a whole in determining whether the presumption should be displaced, and not just the commercial expectation, consequence or effectiveness of the contract. In embarking on this exercise the judge ought not to be fettered by precedent in determining what type of factors are significant. For example, a factor such as the place of payment may be a significant factor for the creditor in respect of a contract of guarantee, ${ }^{57}$ but may turn out to be insignificant in another case where no term of the instrument gave the place of payment contractual effect. ${ }^{58}$

\section{Intermediary Approach}

The use of the intermediary approach in deploying the escape clause in the Rome Convention featured in the dissenting opinion of Lord President Cullen in Caledonia. ${ }^{59}$ Most recently, the CJEU in Intercontainer ${ }^{60}$ gave legitimacy to the intermediary approach. The intermediary approach postulates that both the weak and strong presumption approaches are open to objection as they are extreme versions of what is intended in the Rome Convention. ${ }^{61}$ This approach recognises that there is an underlying dilemma and tension between achieving the goals of legal certainty and predictability in commercial transactions on the one hand; and flexibility and justice on the other hand. It advocates that the primary consideration in Article 4 of the Rome Convention is the determination of the law that is most closely connected with a contract in the absence of choice. ${ }^{62}$ The presumption of characteristic performance in Article $4(2)$ is

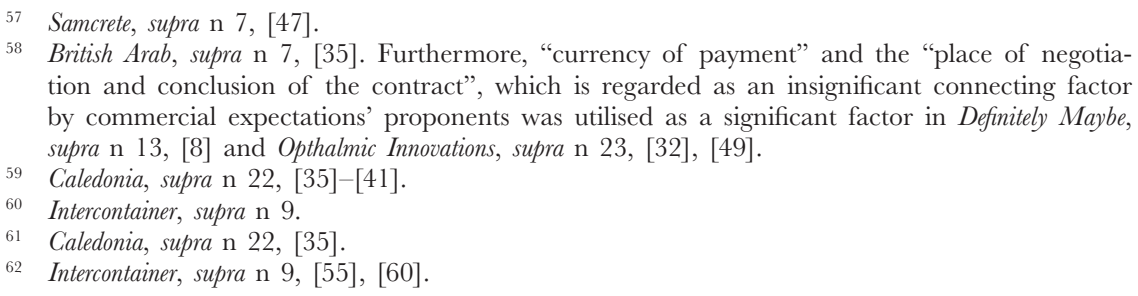


aimed at achieving the goals of legal certainty and foreseeability in the contract between the parties with regard to determining the law that is most closely connected to the contract in the absence of choice. ${ }^{63}$ The escape clause in Article $4(5)$ is aimed at achieving the goal of flexibility and justice in individual cases by leaving a margin of discretion for a judge to disregard the presumption in Article 4(2) if there are other connecting factors that justify such an exercise. ${ }^{64}$

The relationship between Article 4(2) and Article 4(5) involves a counterbalance between the requirements of legal certainty and predictability in commercial transactions on the one hand, and the requirements of flexibility and justice on the other. ${ }^{65}$ Thus, Article 4(2) shall only be disregarded if it appears from the circumstances as a whole that the contract does not have any genuine connecting value or is more closely connected with another country ${ }^{66}$ or it is demonstrated that there is a "clear preponderance of facts in favour of another country". ${ }^{67}$ The intermediary approach as advocated by Lord President Cullen in Caledonia and the Court of Justice of the European Union (GJEU) in Intercontainer is the appropriate, "literal" 68 or "natural meaning" 69 of the deployment of the escape clause in the Rome Convention. The approach is sound and has textual legitimacy in the Rome Convention.

The main advantage of the intermediary approach is that it steers a middle course between meeting the requirements of legal certainty and predictability in commercial transactions on the one hand, and the requirements of flexibility and justice on the other.

However, its major shortcoming is that it does not sufficiently describe the threshold of displacement under Article 4(5). Thus, it is susceptible to manipulation and infiltration by both the weak and strong presumption approaches. In other words, both the weak or strong presumption judicial disciples can claim that they are honouring the intermediary approach as decided by the GJEU in Intercontainer but they can still functionally deploy their extreme versions of the escape clause under the Rome Convention. ${ }^{70}$ This shortcoming is understandable and excusable. Creating an exhaustive list of significant factors that determines the threshold of displacement ultimately fetters the discretion of the judge or decision-maker, and may lead to injustice in individual cases. As stated earlier, a significant factor in one case may turn out to be insignificant

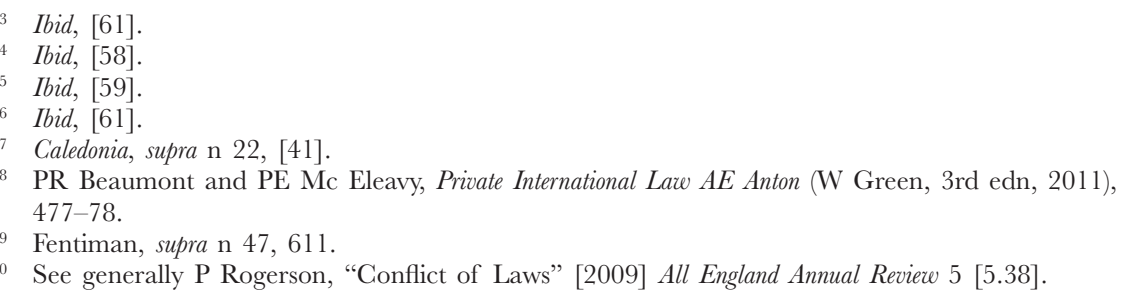


when dealing with the same or another type of contract in the circumstances of the case.

The primary concern of the judge is to weigh the significance of the connections between the contract and the circumstances of the case and the putative law of closest connection. Where the weight of these connections are evenly balanced with, or are outweighed by, the connections with the law of the country selected by the application of the presumption under Article 4(2), then the escape clause should not be deployed.

\section{(a) The Nexus between the Escape Clause and Implied Choice of Law under the Rome Convention}

Despite the CJEU in Intercontainer providing a guide as to how the escape clause should be utilised under the Rome Convention, there are some unresolved matters that still require specific answers from the CJEU. Under Article 3(1) of the Rome Convention a court can imply a choice of law if it is demonstrated with reasonable certainty from the terms of the contract and the circumstances of the case. A court cannot infer the existence of a choice of law as could be done under the common law. Thus, a court can refer to an express choice of court or arbitration clause; or a standard form contract such as the Lloyds Marine Insurance in England; or a previous course of dealings between the parties; or an express choice of law in a related transaction; or a reference to particular rules in a statute to imply a choice of law. ${ }^{71}$

It has caused a great deal of controversy among English judges as to whether the factors utilised in determining the existence of an implied choice of law can be utilised in invoking the escape clause to displace the presumption of characteristic performance. This controversy has survived the decision of the CJEU in Intercontainer. Hobhouse LJ in Credit Lyonnais was of the view that once the court cannot imply a choice of law under Article 3(1) of the Convention "the question of choice and absence of choice becomes irrelevant to the question of ascertaining with what state the contract is most closely connected". ${ }^{72}$ He stated further that such an approach wrongly shifts the focus to "considerations of inferred choice and connections with legal systems and not with the

71 See generally Giuliano and Lagarde, supra n 9, 17; CMV Clarkson and J Hill, The Conflict of Laws (Oxford University Press, 3rd edn, 2006), 177-83 for an exhaustive discussion of these factors. The use of the law governing a closely related contract (eg letters of credit, guarantee and insurance contract) appears to be the most prominent connecting factor in English case law to determine whether the presumption under Art 4(2) of the Convention should be displaced. See generally the cases of Wahda Bank v Arab Bank plc [1996] CLC 408; Bank of Baroda v Vysa Bank Limited [1994] CLC 4 [48]-[49]; Emeraldian Limited Partnership v Wellmix Shipping Limited [2010] EWHC 1411 [171]; Golden Ocean Group Limited v Salgaocar Mining Industries PVT Limited [2011] EHWC 56 (Comm) [134]-[135]; Gard Marine, supra n 56, [39]-[47]; British Arab Commercial, supra n 7, [32]-[34]; Cox v Ergo Versicherung AG (formerly Victoria) [2012] EWCA Civ 1001 [12]-[13].

72 Credit Lyonnais, supra n 6, [916]. 
question of performance and location of the performing parties". ${ }^{73}$ Potter LJ in Samcrete took a tentative view that utilising factors in determining an implied choice of law in deploying the escape clause fails to distinguish the proper role of Articles 3(1) and 4(5) under the Rome Convention. ${ }^{74}$

After the decision in Intercontainer, the High Court in Emeraldian Limited, in disregarding the presumption of characteristic performance (which was in favour of the habitual residence of the guarantor), automatically utilised factors that determine the existence of an implied choice of law while deploying the escape clause. ${ }^{75}$ The Court of Appeal in Gard Marine, per Thomas LJ applied the same approach in disregarding the presumption of Swiss law under Article 4(2) by holding that English law was most closely connected with a reinsurance contract. ${ }^{76}$ The High Court in British Arab, relying on Gard Marine, held that

"the tentative view in Samcrete is overtaken by events by the reasoning in Intercontainer Interfigo. The court is not precluded from taking into account any particular type of factor when applying Article 4(5) and is not required to look at the contract in isolation from other contracts with which it is connected." $" 77$

The Court of Appeal, per Tomlinson LJ in Golden Ocean, overturned the approach of the High Court ${ }^{78}$ per Clarke J, who followed the Court of Appeal's approach in Credit Lyonnais and Samcrete. Tomlinson LJ justified his decision on the ground that a contract of warranty of authority is a special and unique case where utilising the escape clause in terms of legal systems and not the location of the performing parties is a legitimate exercise. ${ }^{79}$ In the case of Lawlor $^{80}$ the High Court held that in utilising the escape clause "the court is concerned with the circumstances as a whole not simply with the pointers to a potential choice of law". ${ }^{81}$

Having regard to the above conflicting English authorities on the nexus between potential factors for determining an implied choice of law and the escape clause under the Convention, the following submissions are made. First, the escape clause in the Rome Convention is couched in terms of the connec-

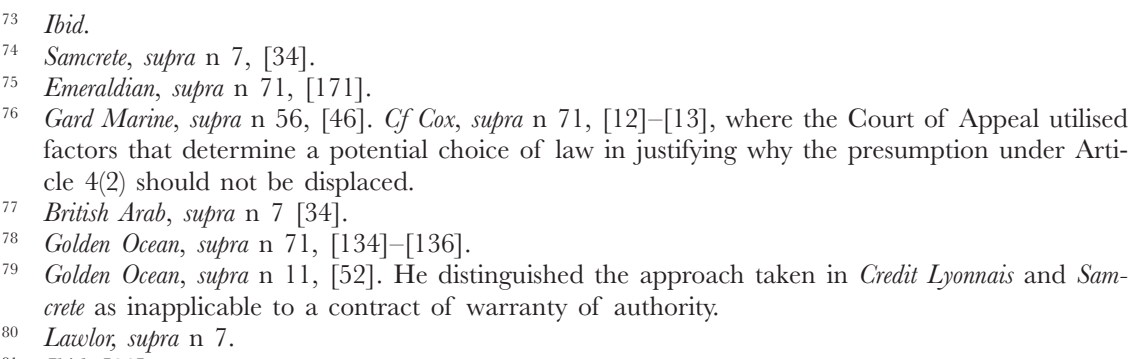
factors that determine a potential choice of law in justifying why the presumption under Article $4(2)$ should not be displaced.

7 British Arab, supra n 7 [34].

Golden Ocean, supra n 71, [134]-[136].

Golden Ocean, supra n 11, [52]. He distinguished the approach taken in Credit Lyonnais and Samcrete as inapplicable to a contract of warranty of authority.

80 Lawlor, supra $\mathrm{n} 7$.

81 Ibid, [60]. 
tion between the "contract" and a "country" and not the connection between the "contract" and a "legal system". ${ }^{82}$

Secondly, there is no aspect of the decision in Intercontainer that legitimises the use of factors that determine an implied choice of law to trump the presumption under Article 4(2). Looking at the circumstances as a whole does not necessarily mean the court should import considerations for a potential choice of law, where these factors are irrelevant in deploying the escape clause.

Thirdly, it is an illegitimate exercise to automatically use factors that determine the existence of an implied choice of law to displace the presumption of characteristic performance, where these factors are irrelevant or insignificant in deploying the escape clause. It creates uncertainty in making the presumption functionally weak and obscures the distinction between a choice of law and law in the absence of choice.

Fourthly, the circumstances of the case should determine whether potential factors used in determining an implied choice of law can also be utilised in invoking the escape clause. For example, Lawlor ${ }^{83}$ concerned the law that should govern the agency relationship between the parties. The characteristic performer (the agent) carried out the bulk of his obligations in Spain. The place of performance of the agency was largely concentrated in Spain and the connection with other countries such as England was very tenuous. However, every contract the parties entered into was governed by English law save for their employment and agency contracts. The High Court rightly held that under Article 4(5) the Spanish connection was much deeper and more extensive than that of England even though there were some pointers to a potential implied choice of law that were not strong enough to constitute such a choice under Article 3.

In Gard Marine ${ }^{84}$ the characteristic performer in the reinsurance contract was located in Switzerland. However, there were connections with England showing that the reinsurance involved a London Market placement (and not one separate Swiss placement); the expiring excess of loss reinsurance was a London market placement; the renewal was a London market placement; and that the underlying policy was governed by English law. Thus, the Court of Appeal decided that there was a real choice of English law under Article 3 of the Rome Convention. ${ }^{85}$ If the Court of Appeal were to be overturned on its

82 This underlies the difference between Art 4(5) of the Rome Convention and Art 4(4) of Rome I. Art $4(4)$ is concerned with the "law of the country" with which the contract has its closest connection - which is similar to the default rule in Art 4(1) of the Rome Convention. Art 4(5) of the Rome Convention and Art 4(3) of Rome I are concerned with the country with which the contract is more (or manifestly more) closely connected with in displacing the main rule. See generally Beaumont and McEleavy, supra n 68, 461-63.

83 Lawlor, supra n 7, [59]-[60].

84 Gard Marine, supra n 56.

${ }^{85}$ Ibid, [37]-[45]. 
Article 3 decision, it took the view that English law should be applied as England was the country most closely connected to the contract under Article 4(5) of the Rome Convention for the reasons given by the court in respect of the considerations under Article 3. ${ }^{86}$

Based on the fourth submission, it is the view here that the Court of Appeal's decision in Golden Ocean is open to objection. The case (among others) concerned the law applicable to a contract of warranty with a third party. There was a contest as to the applicability of English law or Indian Law to the relationship. The High Court per Clarke J rightly focused on the relationship between the parties to the contract of the warranty of authority; and held that since the parties were both habitually resident in India, where the said authority was alleged to have been secured, Indian law should be the applicable law. Furthermore, Indian law would ordinarily be the applicable law if the challenge to the existence of a contract with the third party was successful. ${ }^{87}$ The Court of Appeal per Tomlinson LJ in overturning this part of Clarke J's judgment took the position that since the principal contract in question concerned the contract of guarantee and charter party, which were both governed by English law, the ancillary contract involving the alleged breach of a contract of warranty of authority should also be governed by English law. ${ }^{88}$ Tomlinson LJ was happy to arrive at that conclusion by implying a choice of English law to the contract of warranty of authority under Article 3 of the Rome Convention, even though this point was not argued before the judge or the Court of Appeal, but felt that the same result could be arrived at under Article 4(5). ${ }^{89}$

It is respectfully submitted that this is a case where utilising the factors for a potential implied choice of law under Article 3 should have been irrelevant in deploying the escape clause under Article 4(5). The Court of Appeal ought to have focused on the main contract of warranty of authority (as the lower court did) instead of concerning itself with the existence of the applicability of English law to the contract of guarantee and charter party. The third party had

86 Ibid, [46]-[47]. Cf Cox, supra n 71, [12]-[13]. In Cox there was a contention as to whether German law or English law applied to the assignment of a cause of action by the claimant to the Ministry of Defence (MOD) in England, involving a fatal accident of a British serviceman (claimant's husband) killed in a road accident while posted in Germany. The claimant was habitually resident with the deceased in Germany at the date of the assignment. The assignment was intended to enable the MOD in England to recoup from the tortfeasor, who was a German national or the deceased's German insurer. The cost of the outlays arising from the accident and those claims were governed by German law. The Court of Appeal held on these facts that the connection with Germany outweighed that of England, and German law was the applicable law under Art 3(1). The Court of Appeal rightly that the same results would be reached under Art 4 in refusing to displace the presumption of Art 4(2) in favour of English law, as Germany was the country with which the assignment was most closely connected.

${ }^{87}$ Golden Ocean, supra n 71, [136].

88 Golden Ocean, supra n 11, [52]-[54].

89 Ibid, [49]. 
no proximate relationship with the contract of warranty of authority, which was an entirely separate issue in the case. ${ }^{90}$

Consequently, in view of the confusion and uncertainty created between the nexus of potential factors for an implied choice of law and the escape law, it is proposed that the doctrine of implied choice of law should be deleted in the revised version of the Rome I. ${ }^{91}$ Either the parties make an express choice of law to govern their contract or they do not make one. The objection to this proposal is that it creates a narrow view on party autonomy.

This objection to this proposal is outweighed by four main considerations. First (as demonstrated above), it has caused a great deal of confusion among English courts as to when a court should imply a choice of law or apply the default rule. Secondly, it is uncertain what factors are principally (or primarily) to be utilised in determining an implied choice of law or deploying the escape clause. ${ }^{92}$ Thirdly, where the parties have not made an express choice of law, the court is ultimately left with the decision of determining the applicable law either by implying a choice of law or determining it by default; and factors that are used in determining if the parties had implied a choice of law may turn out to be relevant or significant in deploying the escape clause. Fourthly, some English courts that reach a decision that the parties made an implied choice of law move on to consider what their decision would be if they had been wrong that a choice of law could not be implied by the parties. ${ }^{93}$

It is submitted that this proposal would create a balance between certainty and flexibility. It would be a strong attraction for the parties to make an express choice of law to govern their contract or leave it for the court to decide. The

90 Furthermore, the contract of guarantee and charter party, and that of the contract of warranty of authority, should not have been grouped as closely related contracts. The contract of warranty of authority was primarily concerned with whether one of the parties to the contract had warranted his authority for his company to enter into a contract with a third party. The existence of a contract of guarantee and charter party and the existence or validity of the company entering into that contract was another issue. The contract of warranty of authority should clearly have been severed.

91 Art 3(1) of Rome I still preserves the doctrine of implied choice of law. The only difference is that Art 3(1) of Rome I adds the word "clearly". It is submitted the addition of the words "clearly" does not materially change the intended effect of the implied choice being "demonstrated with reasonable certainty from the terms of the contract and the circumstances of the case". In this regard, Fentiman, supra n 47, 196 rightly submits that the addition of the word "clearly" in Art 3 of Rome I "may simply articulate more precisely what was always contemplated".

92 For example uncertainty has been created as to whether closely related contracts belong to Arts 3 or 4. Giuliano-Lagarde, supra n 9, 17 groups such factors as matters under Art 3, but recitals 20 and 21 to Rome I expressly group it under Art 4. See generally Fentiman, supra n 47, 200-01.

93 When English courts adopt this approach, they reach the decision that the implied choice of law is more closely connected with the contract in applying the escape clause. The inference to be drawn is that the courts that adopt this approach are not sure a choice of law can be implied between the parties with reasonable certainty. Secondly, the court can achieve the same result in implying a choice of law or determining it in the absence of choice. 
deletion of the doctrine of implied choice of law would not bar the court from considering any factor (including potentials for an implied choice of law), where it is relevant or significant in determining the country that is manifestly more closely connected with the contract.

\section{G. The Escape Glause in the Rome I Regulation}

Rome I presents a different structure from the Rome Convention on the determination of the law that applies to a contract between the parties in the absence of choice. Due to strong criticisms regarding the abuse of the escape clause in the Rome Convention to mostly favour the law of the forum of Member States and its leading to so much uncertainty, the Commission's proposal had initially favoured the complete abolition of the escape clause from Rome I. ${ }^{94}$ It is believed that it was criticisms from the academic community that saved the escape clause in Rome I from extinction. ${ }^{95}$

Article 4(1) of Rome I presents a structure of fixed rules (as opposed to presumptions in the Rome Convention) in determining the law that applies to the contract of the parties in the absence of choice. ${ }^{96}$ Article 4(2) functions as an exception to Article $4(1)$ by providing that the contract shall be governed by the law of the country of the habitual residence of the party who is to carry out the characteristic performance based on two conditions. ${ }^{97}$ The first is where "the contract is not covered by paragraph 1". The second is where "the elements would be covered by more than one of the points (a) to (h) of paragraph 1". The escape clause is provided for in Article 4(3) to the effect that where "it is clear from all the circumstances of the case that the contract is manifestly more closely connected with a country other than that indicated in paragraphs 1 or 2, the law of that other country shall apply". Article 4(4) of Rome I provides that where "law applicable cannot be determined pursuant to paragraphs 1 or 2 , the contract shall be governed by the law of the country with which it is most closely connected".

The difference between Article 4(3) and Article 4(4) is that while Article $4(3)$ is concerned with displacing the applicable rules in Article 4(1) and (2) in

94 Proposal for a Regulation of the European Parliament and the Council on the law applicable to contractual obligations (Rome I), 15 December 2005, COM(2005) 650 final, Art 4.

95 S Dutson, "A Dangerous Proposal: The European Commission's Attempt to Amend the Law Applicable to Contractual Obligations" [2006] Journal of Business Law 608, 610-14; Hein, supra n 44, 483-84; Cheshire, North and Fawcett, supra n 6, 724. However, Member States in the Council were not keen on the Commission's proposal to abolish the escape clause. The proposal had not been based on a proper academic or empirical study.

96 It lists eight categories of contract such as contract of sale, provision of services, immovable property, distributorship, franchise, auction sales and financial instruments in which the law of the country of one of the parties is to apply.

97 Recital 19 to Rome I. 
favour of the country that is manifestly more closely connected with contract, Article 4(4) is concerned with locating the law of the country that has the closest connection with the contract without concerning itself with displacing the applicable rules in Article 4(1) and (2). ${ }^{98}$ The candidates for the closest connection test are contracts that do not fall within the fixed rules in Article 4(1), such as letters of credit transactions; and complex contracts involving mutual obligations where the characteristic performer proves difficult or impossible to identify such as in joint venture intellectual property transactions, and transfers of shares. ${ }^{99}$

Rome I does not expressly provide a role for dépeçage as did the Rome Convention, but there remains an argument as to whether its existence is still preserved to be left at the discretion of courts of Member States. ${ }^{100}$ The view held here is that dépeçage has no place in Rome I based on two main reasons. First, it is not expressly mentioned in Article 4 of Rome I. ${ }^{101}$ Secondly, the high bar set by the CJEU in Intercontainer in stating that splitting the applicable law (which is expressly provided for in Article 4 of the Rome Convention) should only be deployed on exceptional grounds is good reason to hold that

98 Scott v West and others; Mackie v Baxter and Others [2012] EWHC 1890 (Ch) [10]-[11]; see generally Beaumont and McEleavy, supra n 68, 483-87.

99 Scott, ibid; Apple Corps Limited, supra n 12, [47]-[64]. The latter case involved a trade mark agreement imposing negative obligations on the parties. The High Court could not identify the characteristic performer under Art 4(2) of the Rome Convention and applied the law of the country that was most closely connected with the contract through the default rule in Art 4(1) of the Rome Convention. This case will prove to be useful in interpreting Art 4(4) of Rome I. Beaumont and McEleavy, ibid, make an interesting comparison between CJEU cases on the Brussels I Regulation - Council Regulation (EC) 44/2001 of 22 December 2000 on Jurisdiction and the Recognition and Enforcement of Judgments in Civil and Commercial Matters [2001] OJ L12/1 ("Brussels I") that discussed the determination of characteristic performance under Art 5(1) of Brussels I and rightly submit that a happy synergy can be created by utilising such decisions as a guide in determining whether Art 4(4) of Rome I should be resorted to. The CJEU case of Car Trim GmbH v Key Safety Systems (C-381/08) [2010] ECR I-1255 [40]-[43] indicated some criteria for distinguishing a sale of goods contract from that of provision of services in determining whether it should be grouped as a contract in which the characteristic performer can be identified. Falco Privatsitung and Rabitsch v Weller-Lindhorst (C-533/07) [2010] ECR I-3327 [36], [41] made a negative pronouncement excluding a contract under which the owner of an intellectual property right granted its partner the licence to use that right in return for remuneration as not being a contract for the provision of services. In the English case of Reliance Globacom Ltd v International Solutions SA [2011] EHWC 1848 (QB) [12], the High Court held that a contract for recovery of outstanding charges to buy capacity on cable network was one in which the characteristic performer could not be identified under Article 5(1)(b) of Brussels I.

100 Plender and Wilderspin, supra n 16, 177; De Miguel Asensio, supra n 33, 201; Magnus, supra $\mathrm{n}$ 8, 31; A Mills, "The Application of Multiple Laws under the Rome II Regulation", in Ahern and Binchy, supra n 6, 133, 149-50.

101 In the Irish case of ICDL GCC Foundation FZ-LLC and others v European Computer Driving Licence Foundation Ltd [2011] IEHC 343 [9.7]-[9.8] the High Court per Clarke J held that Article 4 of Rome II does not provide for dépeçage (as regards deploying the escape clause) since there is no express mention of its use. 
the absence of the mention of its use in Article 4 of Rome I means that it is not to be resorted to.

It is advocated here that the escape clause in Rome I functions in a way similar to the strong presumption approach as opposed to the other three approaches identified in the interpretation of the escape clause in the Rome Convention.

\section{The Resurrection of the Strong Presumption Approach}

The recent GJEU decision in Intercontainer marked the death of the strong presumption approach in the Rome Convention, though it appears that it has been resurrected in Rome I. It is conceded that at the moment no judicial authority has been identified that gives legitimacy to the above opinion. However, having regard to some striking similarities between the phraseology of the doctrine of characteristic performance and the escape clause in the Rome Convention and Rome I, it is appropriate to use the case law authorities from the Rome Convention and recent academic treatises on Rome I to determine the appropriate interpretation of the escape clause in Rome I.

There is a school of thought that holds the opinion that the weak presumption approach may still play a role in the utilisation of the escape clause in Rome I. The opinion is premised on the fact that it is only the structure of Rome I that has changed and not really its content. Thus, courts of Member States "will continue to be confronted with the difficult task of 'counting' and 'weighing' the contacts existing between the contractual relationship and the countries involved". ${ }^{102}$

Fentiman seeks to find a place for the theory of commercial expectations in Rome I. ${ }^{103}$ Fentiman also places emphasis on recitals 20 and 21 to Rome I which provide that in order to determine the law of the country with which the contract is most closely connected, account should be taken, among other things, of "whether the contract in question has a very close relationship with another contract or contracts". Fentiman submits that the "reason is important. It avoids the commercially detrimental result that related contracts are governed by different laws. Implicitly commercial effectiveness animates the search

102 A Bonomi, "The Rome I Regulation on the Law Applicable to Contractual Obligations - Some General Remarks" (2008) 10 Tearbook of Private International Law 175; see generally Cheshire, North and Fawcett, supra n 6, 725; P Charles, "The Evolution of Rome" (2010) 160 New Law fournal 61, 62; E Chvika, "Rome I: Uncertainty on the Horizon of Cross-Border Finance Transaction" (2009) 3 Journal of International Banking and Financial Law 152, 155; E Crawford, "Applicable Law of Contract: Some Changes Ahead" (2010) 4 Scots Law Times 17, 19, 22; Rogerson, supra n 70, [5.38]. Most of those who belong to this school of thought reached their opinion before the recent decision of the CJEU in Intercontainer, which abolished the doctrine of the weak presumption approach under the Rome Convention.

103 Fentiman, supra n 6, 94-98; Fentiman, supra n 47, 213-26. 
for the applicable law". ${ }^{104}$ Fentiman further states that in "determining the law applicable to any given contract the existence of a related contract, connected with a given country, is thus of commercial considerable significance". ${ }^{105}$ Thus, in a letter of credit transaction the same law should govern contracts between the issuing bank and beneficiary, confirming bank and beneficiary, issuing bank and confirming bank. ${ }^{106}$

For reasons earlier advanced on the inappropriateness of using the weak presumption approach and theory of commercial expectations in the Rome Convention, it is submitted they do not have textual legitimacy in Rome $\mathrm{I}^{107}$

There is another school of thought that is of the opinion that the intermediary approach is favoured in Rome I and its adherents advance strong reasons for their opinion. ${ }^{108}$ First, the rules in Article 4(1) and (2) are aimed at legal certainty and foreseeability in the relationship between parties to a commercial transaction, while the escape clause in Article 4(3) retains a degree of flexibility to displace the rules in Article 4(1) and (2) where the country is manifestly more closely connected with the contract. Thus, it represents a balance between requirements of legal certainty and flexibility as handed down by the CJEU in Intercontainer, which is what the intermediary approach aims at. Secondly, Article 4 of Rome I is said to honour the claim contained in recital 16 to Rome I, which has the objective of legal certainty and foreseeable rules, while retaining "a degree of discretion to determine the law that is most closely

104 Fentiman, supra n 6, 95.

105 Fentiman, supra n 47, 218.

106 What if the issuing bank and beneficiary expressly choose English law to govern their contract, the confirming bank and beneficiary choose French law expressly to govern their contract; but the confirming bank and issuing bank make no express choice of law? Certainly, neither English law nor French law could automatically lay claim as being manifestly more closely connected with the contract. Other connecting factors (not just in commercial terms) between the issuing bank and confirming bank such as the place of payment and performance, terms of the contract and object of the contract, place of negotiation and conclusion of the contract and geographical location of the parties will weigh on the mind of the court in deploying the escape clause. In British Arab, supra n 7, Blair J was faced with an almost similar circumstance, where the counter-guarantee given by $\mathrm{C}$ to $\mathrm{E}$ was governed by English law. The guarantee between $\mathrm{S}$ and $\mathrm{C}$ was governed by Syrian law. However, the counter-guarantee given by $\mathrm{E}$ to $\mathrm{S}$ contained no express choice-of-law clause and there was a contention as to whether English law or Syrian law applied. Blair J decided that there was no real choice of Syrian or English law under Art 3 of the Rome Convention [30]. The court then turned its attention to Art 4 of the Rome Convention and rightly refused to deploy the escape clause in favour of Syrian law because the guarantee between $\mathrm{S}$ and $\mathrm{C}$ was governed by Syrian law. It also did not utilise the escape clause in favour of English law because the counter-guarantee given by $\mathrm{C}$ to $\mathrm{E}$ was governed by English Law. The court reached its decision on other grounds by deploying the escape clause in favour of Syrian Law [35].

107 See infra, Section B.

108 O Lando and PA Nielsen, "The Rome I Proposal" (2007) 3 Fournal of Private International Law 29, 38; Cheshire, North and Fawcett, supra 6, 725; ZS Tang, "Law Applicable in the Absence of Choice: The New Article 4 of the Rome I Regulation" (2008) 71 Modern Law Review 785, 798; Beaumont and McEleavy, supra n 68, 475. 
connected" to the contractual relationship in the absence of a choice made by the parties. Thirdly, it is also argued that the strong presumption approach is

"not even consistent with the much tighter wording of the Rome I Regulation because it is possible for the law indicated by the presumption (rule under Rome I) to have 'real significance' and yet for another law to be 'manifestly' more closely connected to the contract." 109

It is submitted that although the escape clause in Rome I is theoretically aimed at an intermediary approach, its phraseology and textual operation makes it function in practice as one that is similar to the strong presumption approach. ${ }^{110}$

First, the escape clause does not need to be resorted to very often as Article $4(1)$ and (2) may often have sufficient connection to the dispute to justify its application. Secondly, the use of the phrases "clear from all the circumstances of the case" and "manifestly more closely connected" in Article 4(3) of Rome I indicates that the escape clause is an exceptional remedy that is to be rarely utilised in determining the law of a country that applies to a contract between the parties in the absence of choice. ${ }^{111}$ In other words, the escape clause should not be utilised if the connecting factors with the law of another country are of similar weight to those indicated by the rules in Article $4(1)$ or (2). ${ }^{112}$ The

109 Beaumont and P McEleavy, ibid.

110 See generally De Miguel Asensio, supra n 33, 204; Magnus, supra n 8, 48; Plender and Wilderspin, supra n 16, 196; G. Alferez, "The Rome I Regulation: Much Ado About Nothing?" (2008) 2 European Legal Forum 61, 70; http://www.cjel.net/online/15_2-vernooij/. Accessed on 17 July 2011. NW Vernooij, "Rome I: An Update on the Law Applicable to Contractual Obligations in Europe" (2009) 15 Columbia fournal of European Law 71, 75; A Briggs, "When in Rome, Choose as the Romans Choose" (2009) 125 Law Quarterly Review 191, 192. In taking the position that Rome I is similar to the strong presumption approach, the writers should not be misunderstood as adopting the approach of the Dutch and Scottish Courts under the Rome Convention, which states the escape clause should only be utilised where the presumption has no significance as a connecting factor.

111 See the Explanatory memorandum from the Commission, accompanying the Proposal for Rome II, COM(2003) 427 final (Explanatory Memorandum) 12.

112 For example in British Arab, supra n 7, there was a contest as to whether the applicable law to the contract of counter-guarantee between E and S was English or Syrian law. The characteristic performer was $\mathrm{E}$, who was the guarantor under the contract. In a bid to utilise the escape clause, E relied on the following significant connecting factors: (i) any claim or demand by $\mathrm{S}$ for payment under the counter-guarantee would have to reach $\mathrm{E}$ in London; (ii) any payment by $\mathrm{E}$ to $\mathrm{S}$ was due to be made in S's account in London, (iii) the key element of performance under the counter-guarantee was the honouring of the undertaking of $\mathrm{E}$ as guarantor, which was located in England. However, S relied on the following significant connecting factors: (i) the underlying contract and infrastructure project was in Syria; (ii) the place of payment under the bond was to be in Syria; (iii) the fact that for the counter-guarantee to be triggered there must be a "claim" under the performance bond, and what counts as a claim was a matter of Syrian law. Although Blair J relied on the last connecting factor as very material in displacing the presumption of English law in favour of Syrian law, it is submitted here that under Rome I, having regard to the fact that the connecting factors between Syria and England were evenly balanced and competed favourably with each other, it should be a clear case where the High Court should hold that Syria was not manifestly closer to the contract to displace the presumption of English law. 
preponderance of other connecting factors required in displacing the rules in Article 4(1) or (2) must be overwhelming, very significant or "obvious and natural". ${ }^{113}$ Connecting factors such as the object of the contract, place of performance, place of common residence or nationality of the parties and business of the parties may constitute strong reasons for invoking the escape clause. ${ }^{114}$

Another significant connecting factor is that expressly identified in recitals 20 and 21 to Rome I, which is based on a contract that has a very close relationship with another contract or contracts. This provision may make the escape clause "more readily satisfied than on first sight". ${ }^{115}$ Contracts that readily come to mind are letters of credit transactions, guarantee agreements and insurance that both involve a multiple of independent contracts between the parties involved. Thus, the judicial authorities used in the Rome Convention in respect of closely related contracts will be of relevance in Rome I. ${ }^{116}$

Finally, it should be noted that it is easier to use the escape clause in Article 4(3) to displace Article 4(2), than Article 4(1). ${ }^{117}$ But there remains a possibility that the escape clause in Article 4(3) can be successfully invoked to trump the fixed rules of Article 4(1) as its sphere of application is not restricted to paragraph 2 but "that indicated in paragraphs 1 or 2 " of Rome I. ${ }^{118}$

\section{Implications of the Difference in Approach between the Rome Convention and Rome I}

The escape clause in Rome I tilts towards more certainty and less flexibility. The major disadvantage of this is that Article 4 of Rome I has "overstretched the aspect of certainty and disregarded too much the aspect of the flexibility and justice to the single case". ${ }^{119}$ Secondly, favouring the law of one party as being applicable to the contract as opposed to the law of the other party

113 Tang, supra n 108, 800. The case of Gard Marine, supra n 56, is a clear example where the connecting factors were overwhelming, very significant and obviously in favour of applying the law of England to displace the presumption of characteristic performance that was in favour of Swiss law. The reinsurance contract substantially revolved around England. The reinsurance involved a London market placement (and not a separate Swiss placement); the expiring excess of loss reinsurance was a London market placement; the renewal was a London market placement; and the underlying policy was governed by English law. The same results would likely be reached under Rome I. Cf Cox, supra n 71, [12]-[13]

114 See generally De Miguel Asensio, supra n 33, 219.

115 Vernooij, supra n 110, 76; cf Tang, supra n 108, 799.

116 Bank of Baroda, supra n 26, [48]-[49]; Marconi Communications, supra n 12, [61]; Habib Bank v CBS [2006] EWHC 1767 [44]; Gard Marine, supra n 56, [40]-[45]; Golden Ocean, supra n 11, [42][45].

117 The principal reason is that the types of case where Art 4(2) has to be resorted to are not the straightforward ones that fit neatly into the fixed rules in Art 4(1) and therefore by definition it will often be hard to identify the characteristic performer. Such unusual and complex contracts are more likely to have another law that might be manifestly more closely connected than the law ultimately selected on the basis of the habitual residence of the characteristic performer.

118 See also De Miguel Asensio, supra n 33, 205.

119 Magnus, supra n 8, 27. 
may be considered as unfair to the other party. On the other hand, the major advantage is that it has entrenched the principles of legal certainty, predictability, foreseeability and uniformity in addressing what law applies to the contract of the parties in the absence of choice. The problem of uncertainty in the Rome Convention has been corrected in Rome I. If the parties want to avoid the rigidity of Article 4 of Rome I, they must make an express choice of law under Article 3 of Rome I. ${ }^{120}$ Indeed, the approach of the European legislators in choosing certainty over flexibility in Rome I should be applauded. This is because in most commercial transactions parties to the contract have ample opportunity to make an express choice of law to govern their contract.

\section{The Escape Glause in the Rome II Regulation}

Article 14 of Rome II grants parties the right to make an agreement on the law that governs their non-contractual relationship before or after the tort occurs. This is a right that is hardly ever exercised because in the ordinary course of events parties do not prepare agreements to govern their non-contractual relationship. ${ }^{121}$ In the same vein, whenever a tort occurs, the likelihood of parties agreeing on a law that will govern their relationship is rare because the tortfeasor will be interested in a law that limits his liability and the compensation he should pay as opposed to the interest of the victim. ${ }^{122}$

Thus, Article 4 of Rome II supplements the provision of Article 14 in the event the parties fail to make a choice of law to govern their non-contractual obligation. Article 4(1) provides as a general rule that the law that applies to a tort/delict is the law of the place where the damage occurs, irrespective of the place that gives rise to the damage and where the indirect consequences of the event occur. ${ }^{123}$ Article 4(2) provides (as an exception) that where the parties are habitually resident in the same country at the time the tort occurs, the law of their common habitual residence will be the applicable law. ${ }^{124}$ Article 4(3) (as an escape clause) provides that where "it is clear from all the circumstances of the case that the tort/delict is manifestly more closely connected with a country other than that indicated in paragraphs 1 or 2, the law of that other country shall apply". It also provides that a "manifestly closer connection with another country might be based in particular on a pre-existing relationship between

\footnotetext{
120 Magnus ibid, 30; Hein, supra n 44, 484.

121 T Kadner Graziano, "Freedom to Choose the Applicable Law in Tort-Articles 14 and 4(3) of the Rome II Regulation" in Ahern and Binchy, supra 6, 113-14.

122 Ibid.

123 See also recitals $17 \& 18$.

124 See also recital 18.
} 
the parties, such as a contract, that is closely connected with the tort/delict in question". ${ }^{125}$

The escape clause in Rome II honours the claim that the law of the place of injury and place of common habitual residence in Article 4(1) and (2) are not exhaustive solutions to the law applicable to non-contractual obligations. ${ }^{126}$ The wording of the escape clause in Article 4(3) is intended to produce some degree of flexibility in Rome II. ${ }^{127}$ However, the use of the phrases "clear from all the circumstances of the case" and "manifestly closer connection" indicate that it is to operate in an exceptional manner. ${ }^{128}$ The rationale provided by the Commission for the approach to making the escape clause exceptional in Rome II stems from the abuse of the escape clause in the Rome Convention by courts of Member States. ${ }^{129}$ Thus, the escape clause is tightly worded in such a way as to enhance legal certainty, uniformity and predictability, and to prevent forum shopping. ${ }^{130}$

Recital 14 to Rome II states that the escape clause should be utilised in such a way as to meet the "requirements of legal certainty and the need to do justice in individual cases". There has been a great deal of debate as to whether the escape clause in Article 4(3) honours that claim. This section seeks to address the possibility of a useful and flexible escape in Article 4(3) clause that also meets the requirement of legal certainty.

\section{Relevant Connecting Factors in Article 4(3)}

The escape clause in Rome II does not provide an exhaustive list of the relevant connecting factors that can be utilised to displace Article 4(1) or (2) but does mention "a pre-existing relationship between the parties, such as a contract". It is suggested here that factors such as the residence of the parties, common nationality, family relationship, events relating to the tort and a jurisdiction clause may also be relevant connecting factors that can make the escape clause operate. ${ }^{131}$ These factors are objective and external connecting factors.

125 Other escapes are provided in Arts 5(2), 10(4), 11(4) and 12(2)(c) of Rome II. The escape clause under Rome II focuses on whether the country has a manifestly closer connection and not whether the right to compensation from the tort has a manifestly closer connection: Facob $v M I B$ [2010] EHWC 231 (QB) [33], [40] and [41]. Although the Court of Appeal [2010] EWCA Civ 1208 [38]-[39] overturned the lower court's decision on other grounds relating to the applicability of Rome II, it did not consider the issues relating to the construction of Art 4. In this regard, reference to the lower Court's decision on Art 4 remains useful judicial dicta [46].

126 Explanatory Memorandum, supra n 111, 12.

127 See also recital 14.

128 See also recital 18.

129 Explanatory Memorandum, supra n 111, 12.

${ }^{130}$ Recitals 6, 14, 15, 16 and 31; Bacon, supra n 5, [38]; Facob, supra n 125, [23]-[24].

131 Fentiman, supra n 47, 608-609; Cheshire, North and Fawcett, supra n 6, 800-03; A Dickinson, The Rome II Regulation: The Law Applicable to Non-Contractual Obligations (Oxford University Press, 2008), 341 . 
There exists a debate as to whether other factors such as "parties' legitimate expectations"132 or "a consequence based approach"133 can be utilised in making the escape clause operate. The proponents in favour of this school of thought argue that these connecting factors should have legitimacy in deploying the escape clause in Rome II because these factors have a similar foundation with a "pre-existing relationship" and "common habitual residence", which are expressly identified as exceptions to the main rule in Article 4 of Rome II. ${ }^{134}$ If this view is favoured, the escape clause will have much inbuilt flexibility and ability to do justice in individual cases.

The proponents of the opposing school of thought argue that having regard to the history of Rome II in which similar connecting factors were suggested by the European Parliament ${ }^{135}$ but were rejected, deployment of the escape clause should have no legitimacy in Rome II. ${ }^{136}$ Thus, the deployment of the escape clause should be restricted to external and objective connecting factors only. ${ }^{137}$ If this view is favoured, the escape clause will be more certain and produce more uniformity among courts of Member States. This view is preferred on the ground that utilising subjective factors in deploying the escape clause is likely to lead to so much uncertainty, and forum shopping, which Rome II principally intends to avoid.

\section{Pre-existing Relationship}

One of the connecting factors expressly identified in Article 4(3) that makes the escape clause operate is "a pre-existing relationship between the parties, such as a contract". This approach has been justified as it "respects the parties' legitimate expectations and meets the need for sound administration of justice". ${ }^{138}$ It has also been applauded for its practicality and simplicity. ${ }^{139}$ The following observations are thus made about "pre-existing relationship" as an important connecting factor.

First, it is not certain whether Article 4(3) is concerned with the law of a country where the pre-existing relationship is based or the law governing a pre-

132 Fentiman, supra n 47, 610.

133 RJ Weintraub, "Rome II: Will it Prevent Forum Shopping and Take Account of the Consequences of Choice of Law?" in Ahern and Binchy, supra n 6, 47, 54-55.

134 Ibid.

135 European Parliament Legislative Resolutions on the Proposal for a Regulation of the European Parliament and of the Council on the Law Applicable to Non-Contractual Obligations (Rome II) $(\mathrm{COM}(2003)$ 0427/C5-0338/203-2003/1068 (COD) (Co decision procedure first reading) Article 4 (3).

136 D Wallis, "Rome II - A Parliamentary Tale", in Ahern and Binchy, supra n 6, 1, 2; Dickinson, supra $\mathrm{n} 131,336,340-41$.

137 Ibid. See also Mills, supra n 100, $144-45$.

138 Explanatory Memorandum, supra n 111, 11-12.

139 Symeonides, supra n 1, 204. 
existing relationship such as a contract. ${ }^{140}$ It is submitted here that it is open to both interpretations as there is no provision in Rome II that prevents the court from taking such a stance. Furthermore, it is not all pre-existing relationships that will be governed by an express or implied choice of law governing a contract. Pre-existing relationships can be determined and utilised as a connecting factor by an applicable law of contract in the absence of choice. ${ }^{141}$

Secondly, the use of the word "might" in Article 4(3) indicates that "preexisting relationship" as a connecting factor does not automatically determine if the country is manifestly more closely connected with a tort. Thirdly, "pre-existing relationship" as a connecting factor could prove to be decisive where the law governing the contractual relationship applies to all the parties involved. Thus, in the Irish case of Allied Irish Bank Plc and others v Diamond and Others $^{142}$ there were different contractual and non-contractual relationships and causes of action (involving multiple parties) before the court. The court in a bid to consolidate proceedings utilised Irish law under Article 4(3) because it governed all the employment relationships between the parties in the case. ${ }^{143}$ However, where the contractual relationships between all the parties are capable of severance, and may result in splitting of the applicable law in favour of different countries, a "pre-existing relationship" may not be decisive in deploying the escape clause. Thus, the English case of Alfa Laval Tumba AB $\mathcal{F}^{\circ}$ Alfa Laval Krakow v Separator Spares International Ltd ${ }^{144}$ concerned breach of confidential information carried by the Polish and English parties (both in Poland and England) against an English company. The Polish parties had their employment relationship governed by Polish law, but the English parties did not have their relationship governed by Polish law. The High Court rightly did not utilise the pre-existing employment relationship between the Polish parties in hold-

140 Ibid, 203; Dickinson, supra n 131, 343-44.

141 In Hillside, supra n 5, [40], [41], [46] the case concerned a concerned a claim for damages as to the financial loss suffered by the claimant during betting. The English High Court held that no choice of law had been made to govern their betting regulations and contract. However, the Court in deploying the escape clause under the Rome Convention held that the law that was more closely connected to their contractual relationship was English law. The Court also utilised this pre-existing contractual relationship held to be governed by English law as one of the significant connecting factors in holding that English law was manifestly more closely connected with the non-contractual obligations between the parties under Rome II. See also Sapporo Breweries Ltd v Lupofresh Ltd [2012] EWHC 2013 (QB) [41]-[46], where the Court took the same approach in deploying the escape clause under the Private International Law (Miscellaneous Provisions) Act 1995 ("PIL Act").

142 Allied Irish Bank Plc and others v Diamond and Others [2011] IEHC 505 [4.19]-[4.20].

143 See also Hillside, supra n 5, [46] where English law, which was held to be the proper law of the contract between the claimant and defendant, was utilised as one of the significant connecting factors to govern their non-contractual obligation; and Sapporo Breweries Ltd, supra n 141, [41][46] where the High Court took the same approach in deploying the escape clause under the PIL Act.

144 Alfa Laval Tumba AB \& Alfa Laval Krakow v Separator Spares International Ltd [2012] EWHC 1155 [21]-[24]. 
ing Polish law as the law that was manifestly more closely connected with the breach of confidential information carried out by the English and Polish parties. ${ }^{145}$

If the above proposition is the correct position of the law, then it is respectfully submitted that the High Court's decision in Innovia Films ${ }^{146}$ should be reached on different grounds if the events giving rise to the damage (such as the contractual pre-existing relationship between the parties) had occurred after 11 January 2009. The case concerned breach of confidence regarding a patent. The claimant and defendant had both signed a Confidentiality and Non-Disclosure Agreement for Mutual Disclosure of Information ("NDA contract") governed by the law of Delaware. There was a contest as to whether English, Delaware or Texas law applied to govern the non-contractual obligation of breach of confidence. The High Court applied English law ${ }^{147}$ and refused to apply the law of Delaware ${ }^{148}$ as the law that was manifestly more closely connected with the breach of confidence.

The High Court should apply Delaware law as a decisive factor based on the pre-existing NDA contractual relationship between both parties, which was governed by Delaware law. The connecting factors between English and Delaware law competed as the events giving rise to the damage and the resulting damage were felt in both countries. ${ }^{149}$ The submission by Arnold J that the claimant did not allege any breach of the NDA; or that the facts relied in support of its claim for breach of confidence go beyond the NDA contract as the reason for refusing to apply Delaware would appear to be unduly technical and a very narrow interpretation of pre-existing relationship as a connecting factor under Article 4(3).

\section{(a) Accessory Connection with a Contract and Protection of Weaker Parties.}

Article 4(3) expressly allows the applicability of a law that governs a contractual relationship to govern a non-contractual relationship. It is not certain whether

145 The court refused to split the applicable law in favour of the Polish parties. If the High Court had done so, Polish law would have been manifestly closely connected to the tort based on the pre-existing employment relationship between the Polish parties. See also the Irish High Court case of Spv Sam Dragon Inc v GE Transportation Finance (Ireland) Ltd [2012] IEHC [16]-[18].

146 Innovia Films, supra n 5, [105]-[111]. The Court utilised the common law with regard to the events prior to 11 January 2009 (through the application of the PIL Act) and Rome II with regard to events occurring after 11 January 2009. It is not clear if the judge would have reached the same decision if the events giving rise to the damage such as the pre-existing relationship of the parties had occurred after 11 January 2009.

147 The High Court placed reliance on the following connecting factors: (a) the defendant was an English company acting through its employees that devised the confidential information; (b) the defendant did so in England because its employees were located in England; (c) the defendant disclosed the information partly in England and in Texas.

148 Innovia Films, supra n 5, [105].

149 In fact the judge regarded the resulting damage of unjust enrichment that occurred from the breach of confidence as worldwide since it affected many countries. 
Article 4(3) in applying the law of a contract governing a pre-existing relationship to a non-contractual obligation should subject it to the protection of the weaker party ${ }^{150}$ by deploying mandatory rules of the habitual residence of that party. In other words, can Article 4(3) deprive a weaker party of protection, if the accessory contract of the parties is smuggled through the back door to govern their non-contractual obligations? ${ }^{151}$ There are two principal opposing schools of thought in this area. The first school of thought argues that Article 4(3), which brings party autonomy through the back door, should be jointly read with the explanatory memorandum ${ }^{152}$ and Article 14(2) of Rome II that provides that weaker parties should not be deprived of protection. ${ }^{153}$ Secondly, since the escape clause is an exceptional remedy, the court enjoys a degree of discretion to ensure that the escape clause is deployed in such a way as not to deprive the weaker party of protection. ${ }^{154}$ The second school of thought admits that although the explanatory memorandum and Article 14(2) of Rome II provide that a weaker party should not be deprived of protection, there is nothing in Article 4(3) that expressly deprives the court of the power to apply a law that does not protect a weaker party under the contract. ${ }^{155}$

It is the view here that the first school of thought is preferred as it produces more just results and at the same time does not threaten legal certainty and uniformity since the escape clause is being deployed in an exceptional and discretionary manner. It will make nonsense of Rome II and threaten its synergy and uniformity with Rome I if a law that does not protect the interests of a weaker party under a contract is used to govern a non-contractual obligation in the guise of deploying an escape clause. ${ }^{156}$

150 Such as an employee, consumer or an insured party.

151 ThM De Boer, "Party Autonomy and its Limitations in the Rome II Regulation" (2007) 9 Yearbook of Private International Law 19, 27-28; Kadnar, supra n 121, 125-27; A Rushworth and A Scott, "Rome II: Choice of Law for Non-contractual Obligations" [2008] Lloyd's Maritime and Commercial Law Quarterly 274, 280-81, 303-05.

152 Explanatory Memorandum, supra n 111, 12-13.

153 Kadner Graziano, supra n 121, 127-29.

154 Ibid. This appears to have been the approach favoured by the English High Court in Hillside, supra n 5, [42], [43] and [46]. The High Court in utilising English law as the law governing the pre-existing contractual relationship between the parties and one of the connecting factors in deploying the escape clause under Art 4(3) of Rome II, also considered if the law protected the claimant (consumer) as a weaker party. Cf Sapporo Breweries Ltd, supra n 133, [41][46, [55], where the High Court appears to have taken a different approach in deploying the escape clause under the PIL Act. The High Court held that Japanese law applied to the noncontractual relationship between the parties based on the pre-existing relationship governed by Japanese law. The High Court did not refrain from applying Japanese law where it did not protect the party that alleged economic duress.

155 Cheshire, North and Fawcett, supra n 6, 802-03; Dickinson, supra n 131, 345-47. Moreover, it is reasoned that the Explanatory Memorandum, supra n 111, 13 states that it applies to void or annulled contracts and pre-contractual relationships such as annulled contracts and family relationships.

156 Recital 7 to Rome I. 
It has been suggested that in order to create certainty parties should make it clear that the law that governs their contract should also govern any noncontractual relationship arising from the contractual relationship and make it clear that it protects weaker parties. ${ }^{157}$ In future amendments of Rome II, it should be expressly provided that utilising a pre-existing relationship as a connecting factor in deploying the escape clause should not deprive a weaker party of protection it would have been entitled to under the law applicable by virtue of Article 4(1) or (2).

\section{The Relationship between Article 4(3), (2) and (1) in Rome II ${ }^{158}$}

There appears to be another contest between certainty and flexibility in determining the extent to which Article 4(3) can displace the applicability of Article $4(2)$ and (1).

The first issue is whether the applicable law of the country needs to have a weak connection to the tort in order to make the escape clause operational. ${ }^{159}$ The first view is that the escape clause should only be used as an exceptional remedy in order to achieve the aims of legal certainty, predictability and uniformity. It is advocated that utilising the escape clause where the main rule does not have a weak connection to the tort will defeat these aims. The opposing view is that from a literal reading of Article 4(3), the escape clause can legitimately be deployed where the law of a country has a "manifestly closer relationship" with another country "other than that indicated in paragraphs 1 or 2 " even where the main rule has significance. ${ }^{160}$ The latter view is preferred as it also honours the requirement of achieving a balance between legal certainty and flexibility in recital 14 . A contrary interpretation will unduly circumscribe the operation of the escape clause and make it too rigid.

The second issue is whether Article 4(3) can utilise the excluded connecting factors in the "place giving rise to the damage" and the "place where the indirect consequences of the event occur" in Article 4(1) to make the escape clause operable. The first view is that adopting such a stance will subvert the main rule in Article 4(1). ${ }^{161}$ Furthermore, Article 17 also indicates that it is only as a matter of evidence that the "place of conduct" may be taken into account for the purpose of accessing the conduct of the tortfeasor. ${ }^{162}$

157 Beaumont and McEleavy, supra n 68, 626.

158 See also Fentiman, supra n 6, 89-91.

159 Ibid, 103-04; Fentiman, supra n 47, 610.

160 Dickinson, supra n 131, 343; Symeonides, supra n 1, 198; Beaumont and McEleavy, supra n 68, 647.

161 This appears to have been the approach taken in the Irish case of SPV Sam, supra n 145, [18] in excluding indirect consequences as a connecting factor while deploying the escape clause. See also Fentiman, supra n 6, 99-100; Fentiman, supra n 47, 608-09.

162 Symeonides, supra n 1, 213. 
The opposing view is that Article 4(3) can utilise connecting factors excluded in Article 4(1) such as the "place giving rise to the damage" and "place where the indirect consequences of the event occur" to make the escape clause operable. The thrust of the argument lies on the ground that the escape clause makes the general rule inapplicable where the tort is manifestly more closely connected with another country. ${ }^{163}$ The latter view is preferred because if such factors are excluded, the escape clause will be unduly circumscribed and rendered redundant to do justice in individual cases. ${ }^{164}$

The third issue is whether Article 4(3) can mediate between Articles 4(2) and (1) in such a manner that the escape clause is used to trump Article 4(2) in favour of Article 4(1). ${ }^{165}$ In other words, must Article 4(3) only be utilised in favour of the law of a third country that is not the place of damage or common habitual residence? ${ }^{166}$ The first view is that Article 4(2) is an exception and inflexible rule to Article 4(1) and does not require any form of displacement in favour of Article 4(1). To do so will threaten legal certainty and predictability. ${ }^{167}$

The opposing view envisages the possibility of Article 4(3) making Article 4(1) applicable by displacing Article 4(2). ${ }^{168}$ But this is likely to occur where the place of damage competes and coincides with the common habitual residence. Furthermore, there must be other strong connecting factors in the place of damage (like pre-existing relationship) that makes the application of Article 4(1) manifestly closer to the tort than Article 4(2). ${ }^{169}$ This view is preferable as

163 Burton J's judicial dicta in Alliance Bank, supra n 5, [38]. This appears to be the general judicial approach especially with regard to utilising events that give rise to the damage: Facob, supra n 125, [39]-[42]; Hillside, supra n 5, [40]-[46]; Alfa Laval, supra n 144, [21]-[ 24]; ICDL GCC Foundation, supra n 101. See also Dickinson, supra n 131, 341; Dicey, Morris and Collins, supra n 7, 196.

164 It may even render the escape clause useless. For example, in a tort of unlawful misrepresentation (or negligent misstatement); the event giving rise to the tort is the making the unlawful misrepresentation in country $\mathrm{A}$, and the indirect consequences of the reliance on the unlawful misrepresentation is the damage suffered by person $(\mathrm{s})$ who were not parties to the contractual relationship in countries $\mathrm{B}, \mathrm{C}$ and $\mathrm{D}$. If the event giving rise to this tort and the indirect consequences are excluded, identifying the country that is manifestly more closely connected to the tort may prove useless. See also the case of VTB, supra n 5, [151]-[162].

165 Art 4(3) is likely to operate more as an exception to Art 4(1) than $4(2)$ due to the inflexibility of Art 4(2).

166 See also Dicey, Morris and Collins, supra n 7, 196-97; Fentiman, supra n 6, 89; Fentiman, supra n 47, 607-08.

167 Fentiman, supra n 6, 89; Fentiman, supra n 47, 607-08 See generally L Heffernan, "Rome II and Implications for Irish Tort Litigation", in Ahern and Binchy, supra n 6, 257, 270.

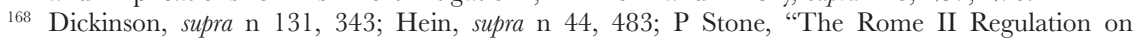
Choice of Law in Tort" (2007) Ankara Law Review 95, 104, 115.

169 It is also submitted that where there is no coincidence or competition between Articles 4(2) and 4(1), Article 4 (3) should not be utilised, if not the very essence of its playing the role as an escape to Article 4 (2) and achieving the primary aim of legal certainty will be defeated. For example A and B are habitually resident in England. B is the agent of A. B carries out business on behalf of $\mathrm{A}$ in Spain and their relationship is governed by Spanish law. B unlawfully misrepresents A in Spain and makes private profit that is not rendered to A. A sues B for 
it honours the requirement of achieving a balance between legal certainty and flexibility as envisaged in recital 14 . In other words, it makes the escape clause in Article 4(3) operate in a flexible manner without threatening the requirement of legal certainty.

In addition, it is also envisaged that the escape clause will come into operation in a manner that does not displace Article 4(1) or 4(2). For example, the escape clause may be an attractive and neat solution where the place of damage proves difficult to identify or occurs in different places as in the case of violation of an intellectual property. ${ }^{170}$

\section{Dépeçage}

Rome II does not expressly provide a role for dépeçage, but there remains a debate as to whether it is to be preserved at the discretion of the court in certain circumstances. The Irish High Court, per Clarke J in ICDL GCC Foundation, ${ }^{171}$ held that, "in the light of the wording of article 4 and in the absence of any jurisprudence from the ECJ to the contrary", dépeçage "is not now available to the courts". However, there are academics who have stated that the idea that dépeçage is excluded under Rome II is by no means free from doubt. ${ }^{172}$

The Irish Court's approach in ICDL GCC Foundation is preferred here and appears to be more supportable. Article 4(3) talks of the law of a country applying to the whole tort and not issues arising out of the tort. Furthermore, it will be an illegitimate exercise to utilise dépeçage that has no express place in Article 4(3) of Rome II. This view is also supported by the CJEU's approach in Intercontainer, which discourages the use of dépeçage even where it is expressly provided for in an instrument.

It has been argued vehemently that the failure to utilise dépeçage in Article 4(3) Rome II marks its greatest flaw, because it makes the escape clause too rigid and of no utility to do justice in individual cases. ${ }^{173}$

unlawful misrepresentation and unjust enrichment. In this case, although, Article 4(2) should apply to $\mathrm{A}$ and $\mathrm{B}$ in respect of the tort of unlawful misrepresentation and unjust enrichment, since they are habitually resident in England; Article 4(3) could be utilised in favour of Spain as the place of damage and the law governing their pre-existing contractual relationship in Spain in displacing Article 4(2) in favour of Article 4 (1).

${ }^{170}$ Hillside, supra n 5, [46]; Innovia Films, supra n 5, [107]-[111]; Alfa Laval, supra n 144, [21]-[24]; ICDL GCC Foundation, supra n 101, [9.5]-[9.8]. It has been argued alternatively that such a law should be applied on a distributive basis i.e the law of each country where the damage occurred applying to the tort. See also Hillside, supra n 5, [37].

${ }^{171}$ ICDL GCC Foundation, supra 101, [9.7]; see also Dickinson, supra n 131, 334-35, 342 and Beaumont and McEleavy, supra n 68, 650.

172 Plender and Wilderspin, supra n 16, 538; Mills, supra n 100, 133, 134, 135, 148-150.

173 Symeonides, supra n 1, 200-201; see also EX Kramer, "The Rome II Regulation on the Law Applicable to Non-Contractual Obligations: The European Private International Law Tradition Continued" (2008) 4 Nederlands Internationaal Privaatrecht 414, 422-23; Mills, supra n 100, $144-45$. 
There are writers and judges who disagree with this viewpoint. First, it is advocated that the failure to utilise dépeçage meets the requirement of legal certainty and flexibility. ${ }^{174}$ Secondly, assuming dépeçage makes the escape clause more flexible, it will complicate the conflicts system in Rome II and lead to some incongruous solution in assessing liability and compensation. ${ }^{175}$ Thus, in Alfa Laval ${ }^{176}$ Arnold $\mathrm{J}$ viewed the suggestion of splitting the applicable law in favour of both the Polish parties and English parties, by applying English law and Polish law with respect to the alleged unlawful conduct of breach of confidential information as "lacking in common sense" and an "unattractive solution". Indeed, the failure to utilise dépeçage in Rome II makes the system more coherent and simple to apply in practice. Furthermore, it reduces the risk of the problems of uncertainty and situations where courts of Member States tailor the escape clause to favour the law of their forum for purposes of compensation.

\section{E. Conclusion}

This paper has discussed the operation of the escape clause in the Rome Convention, Rome I and Rome II with the underlying tension and dilemma of meeting the requirements of legal certainty and flexibility in individual cases.

On the Rome Convention, four approaches were identified as to the manner in which the escape clause should be interpreted. The intermediary approach which is favoured by the CJEU in Intercontainer is applauded here because it reconciles the requirement of legal certainty and flexibility. The Intercontainer decision is a guide for courts of Member States. The discretion of those courts should not be fettered by precedent in determining what connecting factors are significant while deploying the escape clause. The court should look to the nature of the contractual claim in order to weigh its significance as a connecting factor in individual cases.

The GJEU will have to clarify the uncertainty created in English courts with regard to potential factors for determining an implied choice of law and their relevance while determining whether or not to deploy the escape clause.

On Rome I, it was submitted that the escape clause can only function in a manner similar to the strong presumption approach in the Rome Convention. It is admitted that the requirements of flexibility in deploying the escape clause may rarely be met. The stance taken by the European legislators is applauded here because it enhances legal certainty and predictability and makes an express

174 ICDL GCC Foundation, supra n 101, [9.8].

175 Dickinson, supra n 131, 334-35; PJ Kozyris, "Rome II: Tort Conflicts on the Right Track! A Postcript to Symeon Symeonides' 'Missed Opportunity'” (2008) 56 American fournal of Comparative Law 47 1, 477.

176 Alfa Laval, supra n 144, [23]. 
choice of law for the parties to a contract an attractive solution. However, since the doctrine of implied choice of law still appears in the text of Rome I, it is proposed that it should be deleted from the revised version, with the factors that determine an implied choice of law only to be utilised where they are relevant factors in deploying the escape clause.

On Rome II, it was submitted that the escape clause is drafted in a manner that suggests it is to be deployed exceptionally; the escape clause in Rome II operates in an intermediate way. A pre-existing relationship is singled out as a very important factor and it is submitted here that it should be a decisive factor where it governs the contractual relationship of all the parties in the case. However, the court should not deploy the escape clause where the law governing the pre-existing relationship does not protect the weaker party under the contract. The revised provisions of Rome II should take account of this suggestion.

Furthermore, the debate as to whether dépeçage has a role to play in deploying the escape clause in Rome I and Rome II has recently come to the fore. It is considered that it has no role to play.

It is anticipated that some of the issues discussed here, especially regarding the deployment of the escape clause in Rome I and Rome II, will eventually come before the CJEU to lay some of the existing academic and judicial debates to rest. 